\title{
Occupational Stress among Librarian and Library Staff in Universitas Airlangga Indonesia
}

\section{Stres Kerja Pustakawan dan Staf Perpustakaan di Universitas Airlangga Indonesia}

\author{
Ratih Damayanti' ${ }^{1}$ Fadilatus Sukma Ika Noviarmi ${ }^{1}$, Erwin Dyah Nawawinetu', Maisyatus Suadaa \\ Irfana $^{2}$ \\ ${ }^{1}$ Lecturer of Occupational \& Health Safety, Faculty of Vocational Universitas Airlangga \\ ${ }^{2}$ Lecturer of Libriarian Technician, Faculty of Vocational Universitas Airlangga \\ Campus B Universitas Airlangga \\ Jalan Dharmawangsa Dalam Selatan No. 28-30, Gubeng, Surabaya, East Java, 60286 Indonesia
}

\begin{abstract}
Introduction: As the other worker, librarian could be got occupational stress because of their duties. However, the duties of librarians and library staff seem trivial and monotonous to the general public. Precisely because it looks trivial and monotonous, research needs to be done related to work stress experienced by librarians and library staff. Aim of this study were to assessed the work stress experienced by librarians and library staff also analyze work stress related factors among librarians and library staff. Methods: In this observational analytic research that has cross sectional designed, occupational stress level was measured by HSE questionnaire and role conflict, carrier development and responsibility to person in organization were calculated by questionnaire in Manpower Minister Decree number 5 2018. Results: Most of the librarian and library staff experienced moderate level of occupational stress. Analysis of chi-square results proved that role conflicts and carrier development significantly related to occupational stress that was experienced by librarian and library staff in Airlangga University. On the other hand, the other variables of socio-demographic and responsibility to person in organization have no significant relationship. Conclusion: Almost all levels of work stress on librarians and library staff are middle to high level with factors related to role conflict and career development.
\end{abstract}

Keywords: Indonesia, librarian, occupational stress, university

\section{ABSTRAK}

Pendahuluan: Pustakawan merupakan sumber daya penting yang ada di perpustakaan termasuk di Universitas Airlangga. Sebagai pekerja, pustakawan tentu pernah mengalami stres kerja karena tugas-tugasnya. Tujuan penelitian ini adalah untuk menilai stres kerja pada pustakawan dan staf perpustakaan serta menganalisis faktor yang berhubungan dengan terjadinya stres kerja pada pustakawan dan staf perpustakaan. Metode: Penelitian ini adalah penelitian observasional analitik dengan desain crossectional. Tingkat stres kerja diukur menggunakan kuesioner stres kerja yang tercantum pada Permenaker 5 tahun 2018. Hasil: Sebagian besar pustakawan dan staf perpustakaan mengalami stres kerja sedang. Analisis menggunakan chi-square menunjukkan bahwa adanya konflik peran dan pengembangan karir berhubungan dengan stres kerja yang dialami oleh pustakawan dan staf perpustakaan. Di sisi lain, variabel yang terkait dengan sosial demografi dan tanggung jawab terhadap orang di organisasi tidak berhubungan. Simpulan: Hampir semua tingkat stres kerja pada pustakawan dan staf perpustakaan adalah tingkat menengah hingga tinggi dengan faktor yang berhubungan konflik peran dan pengembangan karir.

Kata kunci: Indonesia, pustakawan, stres kerja, universitas

Author for Correspondence:

Ratih Damayanti

Email : ratih.damayanti@vokasi.unair.ac.id

Telephone: +6287855805719

\section{INTRODUCTION}

Stress can be caused by work pressure, busy schedules, bad boss-subordinate relationships, bad relationships between coworkers and other factors that can cause stress. Stress can have psychological 
or physiological effects on humans depending on the source of stress or stressor. As a result of stress, there are alteration that occur in our body when experiencing it continuously or when experiencing stress. If someone could fix it then the condition can be controlled. On the other hand, if a person could not control it would be change into a stressful condition (Gill (2017). Librarians are a vital resource in any library, especially at universities. As a worker, a librarian has a job description in which each job description has a demand. Due to job demands, a worker including a worker can experience stressful work. Samosir and Syahfitri (2008) stated that the causes of work stress on librarians include low remuneration, weak management and supervision systems, low public appreciation of the librarian profession, low level of librarian career and too heavy workload. Librarian in his daily life in addition to giving the carry to users, also do administrative work and work routine, like material selection library, processing library materials, and maintenance of library materials, the work is carried out almost every time day. Work serving users with various types of needs and the questions asked by users require a lot of energy and must be patient and can understand what they want Diverse user needs it demands the librarian to provide information in accordance with information needs they want. If the librarian is confronted with the demands of work are exceeded ability, then it can be said that the librarian experienced work stress Prolonged work stress can cause burnout.

The factor that made workers stressful became an interesting topic research. However, the work stress on the librarian has not been much studied. This was because the nature of work that tends to static, monotonous and and looks easy.. There was just that recently alterated in librarian's work that could be studied especially related to work stress (Shupe and Pung, 2011).

Heavy workloads, less rest time, long hours work and shift work, and less important tasks and an imbalance between worker and job and lack of control are the source of stress on librarians. In addition, job descriptions that are routine, repetitive and difficult to change the design (both work and time) could also cause work stress (The National Institute for Occupational Safety and Health (NIOSH), 2008).

Other research mentioned that the main cause of a librarian to be stress is management/ boss, heavy workload, poor working environment, transportation problem (from home to work), customer, low supervision, difficulty adapting to new technology. Work-related stress experienced by the librarian because of these things could cause effects of dissatisfaction with the job, depression, pain, low productivity, frustration, poor work behavior to absenteeism (Babatope, 2013).

A study proved to be besides factors such as high workload, role ambiguity and role conflict can be one trigger the occurrence of work stress. Role-related ambiguity tend to high in academic librarian and that factor also significantly correlated to all psychological, health related and work-related outcomes. It meant academic librarian whose stress level and burnout in high category they have lack of health condition and low level of job satisfaction (Shupe, Brambleb and Wambaugh, 2015).

In addition to role conflict and role ambiguity, career development also contributes to the occurrence of work stress. This is closely related to job satisfaction felt by librarians and library staff. There was research that showed that job satisfaction is categorized into 2 dimensions of intrinsic and extrinsic. The so-called intrinsic dimension is the work factor itself. While extrinsic dimension comes from outside work such as work environment and compensation received such as salary, partners and policy. These include career development (Raza et al., 2017). A Study in Karachi showed significant correlation between career development and job satisfaction in banking sector. Bank staff in Karachi were satisfied with career development from their company (Shujaat et al., 2013).

Therefore, in this study discusses the relationship between demographic social variables, role conflict, career development and responsibility to whom within the organization and occupational stress in librarian and library staff. The purpose of this study is librarians and library staff in Airlangga University. The factors identified were social demographics (age, sex, education level, years of service, work units and knowledge level.

\section{METHODS}

This study was an observational and analytic research with a cross-sectional design which was held in August, 2018. The study was conducted at the Library of University of Airlangga with large sample of 30 people from 57 persons on population. Each staff filled out a questionnaire containing personal data of age, sex, educational level, knowledge 
Table 1. Socio-demographic Characteristics of Librarian and Library Staff in Universitas Airlangga 2018

\begin{tabular}{|c|c|c|c|c|c|}
\hline Socio-Demographic & Number & Percent & Mean & Minimum & Maximum \\
\hline \multicolumn{6}{|l|}{ Age (years old) } \\
\hline $20-30$ & 2 & 6.7 & \multirow{4}{*}{41.80} & \multirow{4}{*}{28} & \multirow{4}{*}{55} \\
\hline $31-40$ & 11 & 36.7 & & & \\
\hline $41-50$ & 13 & 43.3 & & & \\
\hline$>50$ & 4 & 13.3 & & & \\
\hline Total & 30 & 100.0 & & & \\
\hline \multicolumn{6}{|l|}{ Gender } \\
\hline Male & 10 & $33, .3$ & \multirow[t]{2}{*}{-} & \multirow[t]{2}{*}{-} & \multirow[t]{2}{*}{-} \\
\hline Female & 20 & 66.7 & & & \\
\hline Total & 30 & 100.0 & & & \\
\hline \multicolumn{6}{|l|}{ Educational Level } \\
\hline Elementary School & 1 & 3.3 & \multirow{5}{*}{-} & \multirow{5}{*}{-} & \multirow{5}{*}{ - } \\
\hline Junior High School & 1 & 3.3 & & & \\
\hline Senior High School & 6 & 20.0 & & & \\
\hline Bachelor degree/diploma & 18 & 60.0 & & & \\
\hline Master degree & 4 & 13.3 & & & \\
\hline Total & 30 & 100.0 & & & \\
\hline \multicolumn{6}{|l|}{ Work Unit } \\
\hline Non Service Unit (Not Librarian) & 12 & 40.0 & - & - & - \\
\hline Service Unit & 18 & 60.0 & & & \\
\hline Total & 30 & 100.0 & & & \\
\hline \multicolumn{6}{|l|}{ Work Experience } \\
\hline$<5$ years & 2 & 6.7 & \multirow{4}{*}{16.41} & \multirow{4}{*}{4} & \multirow{4}{*}{28} \\
\hline 5-10 years & 5 & 16.7 & & & \\
\hline $11-20$ years & 14 & 46.7 & & & \\
\hline$>20$ years & 9 & 30.0 & & & \\
\hline Total & 30 & 100.0 & & & \\
\hline \multicolumn{6}{|l|}{ Knowledge Level } \\
\hline Intermediate & 4 & 13.3 & \multirow[t]{2}{*}{8.7} & \multirow[t]{2}{*}{5} & \multirow[t]{2}{*}{11} \\
\hline Advanced & 26 & 86.7 & & & \\
\hline Total & 30 & 100.0 & & & \\
\hline
\end{tabular}

level and work tenure. In addition to personal data, librarians filled out a questionnaire that serves to assess the level of occupational stress, the role of conflict, career development,and responsibility to others in the organization.

This study is a follow-up study in which the first study was conducted in 2017 (Damayanti \& Nawawinetu, 2019). So that the ethical certificate used is the ethical certificate from the Ethics Commission of the Faculty of Public Health that came out in the initial study number 409-KEPK.

Work stress was assessed using the Health and Safety Executive questionnaire. The questionnaire consisted of 35 questions about the experiences experienced by staff related to work and work stress. The questions are rated on a scale of 1-5 (never, rarely, often and often). Then, work stress can be categorized into low, medium and high work stress. While questions about role conflict, career development and responsibility towards others in the organization (Ministry of Manpower Republic of Indonesia, 2018). The questionnaire was assessed on a scale of 1-7 (unheard of, rarely, rarely, occasionally, often, often and always). Then, role conflict, career development and responsibility to others in the organization were categorized as low, medium, and high. The results were then analyzed using SPSS (version 19.0) by chi-square test to 
Table 2. Desription about Occupational Stress, Role Conflict, Carrier Development and Responsibility to Person in Organization of Librarian and Library Staff in Universitas Airlangga 2018

\begin{tabular}{ccc}
\hline Variable & Number & Percent \\
\hline $\begin{array}{c}\text { Occupational-related-stress } \\
\text { Level }\end{array}$ & & \\
Low & 6 & 20.0 \\
Moderate & 22 & 73.3 \\
High & 2 & 6.7 \\
\hline Total & 30 & 100.0 \\
\hline Role Conflict & & \\
Low & 11 & 36.7 \\
Moderate & 18 & 60.0 \\
High & 1 & 3.3 \\
\hline Total & 30 & 100.0 \\
\hline Carrier Development & & \\
Low & 11 & 36.7 \\
Moderate & 19 & 63.3 \\
\hline Total & 30 & 100.0 \\
\hline Responsibility to Person in & & \\
Organization & & \\
Low & 8 & 26.7 \\
Moderate & 19 & 63.3 \\
High & 3 & 10.0 \\
\hline Total & &
\end{tabular}

see whether there was a relationship between job stress and role conflict, career development, and responsibility to others in the organization.

\section{RESULTS}

The data on table 1 was a description of personal data from the staff of central library of Airlangga University. Majority of library staff included librarian are 41-50 years old with an average age of 41.8 years. The youngest age is 28 years old and the oldest age is 55 years old. The number of library staff more women than men. The highest levels of education were diplomas and bachelor degree (mostly from library technician). Most library staff work in the library for about 11-20 years with an average of about 16 years.

The table 2 was an overview of work stress, role conflict, career development and responsibility to others in the Organization. Most of the library staff experienced moderate work stress $(73.3 \%)$. The staff also mostly experienced role conflict $(60.0 \%)$, career development (63.3\%) and responsibility for others in the organization $(63.3 \%)$ were at the middle level. Table 3 showed crosstabulation data between work stress, level of knowledge about work stress, role conflict, career development and responsibility to others in the organization with the aim to understood how far its interconnectedness.

The table 4 showed that socio-demographic variables and occupational stress level. There were no significant correlation between all variables of socio-demographic and occupational stress level $(\alpha<0,05)$. However, it can be noticed that librarian and library staff experienced work stress at the middle of their carrier (they started their carrier at 20 years old and they would be retired at 58 years old). This was reinforced by evidence that staff working for 11-20 years work experience were vulnerable to work stress.

Female librarian and library staf more experienced work stress than male librarian and library staff. Librarian and library staff whose diploma/bachelor degree in their educational level have risk to got more stressful than the other staff. Most staff in the service unit, most of them are librarian, experienced occupational stress (low, medium and high level stress). The lowest division experienced work stress was non service unit. Non service unit were consist of the division of HRD, finance, public relation, IT staff and facilities and infrastructure. Facilities and infrastructure staf experienced mild and moderate work stress. While the other division staff such as HRD, finance, IT and public relations more experienced medium-level work stress.

The result of analysis with Chi-sqaure showed that role conflict $(p=0.001)$ and career development $(p=0.022)$ experienced by library staff had significantly related with work stress. While the level of knowledge $(p=0.256)$ and responsibility to others in the organization $(p=0.416)$ was not related.

\section{DISCUSSION}

The definition of stress depends on the perspective of the researchers. The perspective can start from social, economic to political issues. On early, stress is defined as a stimulus, response or interaction between the two (Heijnis (2003); Dewe, (2001)).

There is a significant relationship between age and work experience (Suci, 2018). This is contrary 
Table 3. Crosstabulation of Description Social-Demographic and Their Occupational Stress of Librarian and Library Staff in Universitas Airlangga 2018

\begin{tabular}{|c|c|c|c|c|c|c|c|}
\hline \multirow{3}{*}{ Variable } & \multicolumn{6}{|c|}{ Occupational Stress Level } & \multirow{3}{*}{ Sig } \\
\hline & \multicolumn{2}{|c|}{ Low } & \multicolumn{2}{|c|}{ Moderate } & \multicolumn{2}{|c|}{ High } & \\
\hline & Number & Percent & Number & Percent & Number & Percent & \\
\hline \multicolumn{8}{|l|}{ Age (years old) } \\
\hline $20-30$ & 0 & 0.0 & 0.0 & 9.1 & 0 & 0.0 & \multirow{4}{*}{0.469} \\
\hline $31-40$ & 2 & 33.3 & 33.3 & 40.9 & 0 & 0.0 & \\
\hline $41-50$ & 2 & 33.3 & 33.3 & 40.9 & 2 & 100.0 & \\
\hline$>50$ & 2 & 33.3 & 33.3 & 9.1 & 0 & 0.00 & \\
\hline Total & 6 & 100.0 & 22 & 100.0 & 2 & 100.0 & \\
\hline \multicolumn{8}{|l|}{ Gender } \\
\hline Male & 2 & 33.3 & 7 & 31.8 & 1 & 50.0 & \multirow[t]{2}{*}{0.873} \\
\hline Female & 4 & 66.7 & 15 & 68.2 & 1 & 50.0 & \\
\hline Total & 6 & 100.0 & 22 & 100.0 & 2 & 100.0 & \\
\hline \multicolumn{8}{|l|}{ Educational Level } \\
\hline Elementary School & 0 & 0.0 & 1 & 4.5 & 0 & 0.0 & \multirow{5}{*}{0.322} \\
\hline Junior High School & 1 & 16.7 & 0 & 0.0 & 0 & 0.0 & \\
\hline Senior High School & 1 & 16.7 & 4 & 18.2 & 1 & 50.0 & \\
\hline Bachelor degree/diploma & 3 & 50.0 & 15 & 68.2 & 0 & 0.0 & \\
\hline Master degree & 1 & 16.7 & 2 & 9.1 & 1 & 50.0 & \\
\hline Total & 6 & 100.0 & 22 & 100.0 & 2 & 100.0 & \\
\hline \multicolumn{8}{|l|}{ Work Unit } \\
\hline $\begin{array}{c}\text { Non Service Unit (Not } \\
\text { Librarian) }\end{array}$ & & 33.4 & 10 & 45.4 & 0 & 0.0 & \multirow[t]{2}{*}{0.73} \\
\hline Service Unit & 2 & 66.7 & 12 & 54.5 & 2 & 100.0 & \\
\hline Total & 4 & 100.0 & 22 & 100.0 & 2 & 100.0 & \\
\hline \multicolumn{8}{|l|}{ Work Experience } \\
\hline$<5$ years & 0 & 0.0 & 2 & 9.1 & 0 & 0.0 & \multirow{4}{*}{0.677} \\
\hline $5-10$ years & 3 & 50.0 & 6 & 27.3 & 0 & 0.0 & \\
\hline $11-20$ years & 2 & 33.3 & 10 & 45.5 & 2 & 100.0 & \\
\hline$>20$ years & 1 & 16.7 & 4 & 18.2 & 0 & 0.0 & \\
\hline Total & 6 & 100.0 & 22 & 100.0 & 2 & 100.0 & \\
\hline \multicolumn{8}{|l|}{ Knowledge Level } \\
\hline Intermediate & 4 & 66.7 & 20 & 90.9 & 2 & 100.0 & \multirow[t]{2}{*}{0.256} \\
\hline Advanced & 2 & 33.3 & 2 & 9.1 & 0 & 0 & \\
\hline Total & 6 & 100.0 & 22 & 100.0 & 2 & 100.0 & \\
\hline
\end{tabular}

to the results of this study which did not show a significant relationship. However, this study showed that increasing age and years of work the higher the level of work stress.

In this study, gender and work stress variables did not have a significant relationship. This is in line with the study of Fitri (2013) which shows that gender and work climate are not significantly related. While other variables such as interpersonal relationships, age and years of service are significantly related. Based on the results of this study and previous studies it can be concluded that both men and women alike have the same chance of experiencing work stress.

The level of education is not significantly related but the higher the education the higher the level of work stress. The results of the study contradict with the results of Irkhami (2015) which showed that the level of education had a strong relationship with the incidence of work stress. 
Table 4. Crosstabulation and Relationship between Occupational Health, Role Conflict, Carrier Development and Responsibility to Person in Organization of Librarian and Library Staff in Universitas Airlangga 2018

\begin{tabular}{|c|c|c|c|c|}
\hline \multirow{2}{*}{ Variable } & \multicolumn{3}{|c|}{ Occupational Stress } & \multirow{2}{*}{$\alpha$} \\
\hline & Low & Medium & High & \\
\hline \multicolumn{5}{|c|}{ Knowledge Level } \\
\hline Intermediate & 4 & 20 & 2 & \multirow[t]{2}{*}{0.256} \\
\hline Advanced & 2 & 2 & 0 & \\
\hline Total & 6 & 22 & 2 & \\
\hline \multicolumn{5}{|l|}{ Role Conflict } \\
\hline Low & 4 & 6 & 1 & \multirow{3}{*}{0.001} \\
\hline Medium & 2 & 16 & 0 & \\
\hline High & 0 & 0 & 1 & \\
\hline Total & 6 & 22 & 2 & \\
\hline \multicolumn{5}{|c|}{ Carrier Development } \\
\hline Low & 5 & 5 & 1 & \multirow{3}{*}{0.022} \\
\hline Medium & 1 & 17 & 1 & \\
\hline High & 0 & 0 & 0 & \\
\hline Total & 6 & 22 & 2 & \\
\hline \multicolumn{5}{|l|}{$\begin{array}{l}\text { Responsibility } \\
\text { to Person in } \\
\text { Organization }\end{array}$} \\
\hline Low & 3 & 4 & 1 & \multirow[t]{3}{*}{0.416} \\
\hline Medium & 2 & 16 & 1 & \\
\hline High & 1 & 2 & 0 & \\
\hline Total & 6 & 22 & 2 & \\
\hline
\end{tabular}

The level of knowledge about work stress was not significantly related in this study. This shows that even though someone has knowledge about work stress does not guarantee a person does not experience work stress.

The National Institute for Occupational Safety and Health (NIOSH) (1998) defined that job stress or occupational stress is "the harmful physical and emotional responses that occur when the requirement of the job do not match the capabilities, resources or needs of the worker. And, job stress can make to poor health and even injury." Some job conditions that could cause job stress among others are the design of task or duties, style of management, relationship among coworkers and supervisors, work role conflicts such as uncertain job expectations, poor of career developments and environmental situations (there are many safety and health hazards).
Role overload, role conflict, role ambiguity and under-participation, feeling inequity also can be the other stressor. They can be categorized as organizational stressor because it occurred in organization itself (Raza et al., 2017).

It can be concluded that stressor could come from internal and external factors. Internal factors can also determined individual or personal factors. While external factors are factors that come from outside the individual self like work environment, social, career development and organizational support (Tarwaka, 2015).

Topper (2007) mentions that stress also occurs in librarians and libraries as organizations. Librarians who experience stressful events need special handling and strategies to reduce stress levels. Strategy and handling are among others training to overcome this. Meanwhile, Farler and BroadyPreston (2012) mentioned that job stress was able to positively affect the librarians that can increase motivation in service to students and can create job satisfaction itself.

A study in India states that job stress on the librarian was divided into 4 , namely stress caused by technology, physical, mental and situational. Stress caused by this technology illustrated that librarians must face the rapid changes in computer hardware or software. While physical stress is described as having a negative impact on physical health. This is related to the working conditions of sitting for long periods of time, exposure to air conditioning, poor rest and diet settings. One of the most vulnerable health effects is sick buliding syndrome. While mental stress was associated with high expectation, fear and regret. While situational stress was more likely due to good role conflict. Librarians who becomes a manager who still adapted to their new role (responsibility to others). Or, there were conflicts with friends and between superiors and managers. Another study mentions that role conflict that occurs in librarians was a disagreement on what has been done by librarians between supervisors with each other (Routray and Satpathy, 2007).

Librarian is the one of work field that has a monotony and repetitive work. Some studies suggest that monotonous and repetitive work can increase the occurrence of work stress compared to other more varied work. Work-related-stress or occupational stress could be defined as there are interactions between and among the outside factors from the worker (surroundings of work, job capacity, organizational situations and worker's 
capacities, and the others include role conflict) and human factors (experience, influence health, work performance and job satisfaction). Poor interaction between occupational conditions and human factors may result in emotional disturbances, behavioural problems like a deviant attitude, and the other mental or physical illness. On the other hand, the working situations and human factors in balance then work creates a feeling of mastery and selfconfidence: increases motivation, working capacity and satisfaction; and improves health (International Labour Organization, 2016).

The routine tasks of library management work are differentiated in 3 sequences, starting from procurement, processing to service. The first tasks is a "procurement", procurement is the activity starts from the selection of library materials, order or purchase directly and collection reception. Before all these activities are carried out, the library needs to survey a collection's strengths and surveys on the needs of library users. The head of the library is in charge of library selection activities

Second task is a "processing". After the library materials are received from the procurement section, the library material begins to be processed. This activity needs to be done carefully, ranging from recording bibliographic data, analyzing the subject, determining the class number and access point (point access), making physical equipment such as labels, plastic covers, cards and book bags. After the library materials are ready, the organizers arrange them on the shelves, as well as the catalog cards arranged in the catalog cabinets, to the monitoring and evaluation of collections. Good processing will facilitate system retrieval (retrieval system) quickly and precisely.

The third task is a "service" is an important task, because this is the part that plays a role in conveying information to users. Users are all employees as well as outsiders who are given permission to obtain services. One important element in service is the officer. The service system is divided into 2 types, namely open service and closed services. Open services let users choose their own libraries of interest from bookshelves or other libraries, while closed services do not allow users directly to the shelf. In this section, the service discussion will be limited.

Coronary heart disease, MSDS and the other problems are new problems that arise due to excessive job stress. Which is the work stress also could be arise due to monotonous and repetitive work (Rissen, 2006). In this research, the most of librarians and other library staff experienced work stress. This is especially true for librarians in the service unit who are experiencing moderate to highlevel work stress.

The work stress experienced by librarians and other library staff was statistically related to role conflict and career development. The role conflict that occurs here is when either a librarian or other library staff feels doing unnecessary tasks or projects. In addition, formal command lines are also often not adhered to and often receive requests or orders from others who are often at odds. In career development, they feel they do not have sufficient opportunities to move forward. And when they want a promotion they have to find work on another work unit. In addition, they also feel less the opportunity to grow and learn new knowledge in their work.

Research in Pakistan shows that there is a significantly related between job stress, role conflict and behavior change. Role conflict has the greatest contribution to the existence of behavioral aberrations (Raza et al., 2017). Role conflict occurs when a person experiences a discrepancy between one's role and another and can create pressure when working. This role conflict starts when there are two requests on one individual and the two requests are not parallel (Kopelman et al, 1983; Kahn, 2010). Deviant behavioural in librarian could be presented by unfriendly attitude to give a service to the other civitas academica such as students, lecturer and the other.

Some research mentioned that career development associated with job satisfaction. Job satisfaction of employees can also succeed the success of a job or business. Thus, the worker is one of the most important components in an organization (Umer and Naseem, (2011); Ashar et al., (2013); Shelton, (2001)). Job satisfaction is fulfilled can be a motivation of a worker to work harder and improve themselves and the organization. Thus, with the fulfillment of job satisfaction can reduce the level of work stress a person.

A study proves that the stressors in the workplace significantly predict the level of job repletion. The greatest influence on the level of job satisfaction comes from organizational control and the interaction between pressure and job conflict (Xiang et al., 2014).

\section{CONCLUSION}

The results of this study indicate that almost all work stress that occurs in librarians and library 
staff is the stress of middle to high level work there is no relationship between social demographic variables such as age, sex, length of work, work unit and knowledge level with work stress. While role conflict and career development have a significant relationship with the occurrence of work stress. Responsibility to others in the organization is also not significantly related.

\section{ACKNOWLEDGEMENT}

This work was supported by The Faculty Annual Performance and Budget Plan based on the Vocational Faculty Dean Decree number 019 / UN3.1.14 / KD / 2017 concerning Research and Community Service Activities.

\section{REFERENCES}

Ashar, M. et al. (2013) 'The Impact of Perceptions of Training on Employee Commitment and Turnover Intention: Evidence from Pakistan', International Journal of Human Resource Studies, 3(1), pp. 74-88.

Babatope, I. S. (2013) 'Causes and Effects of Job Related Stress among Polytechnic Librarians in Delta State, Nigeria', International Journal of Library Science, 2(1), pp. 1-5.

Dewe, P. J. (2001) 'Work Stress, Coping and Well Being: Implementing Strategies to better Understand the Relationship', in Perrewe, P. L. and Ganster, D. C. (eds) Exploring Theoretical Mechanisms and Perspectives. Bingley: Emerald Group Publishing Limited, pp. 63-96.

Farler, L. and Broady-Preston, J. (2012) 'Workplace stress in libraries: A case study', in Aslib Proceedings, pp. 225-240.

Fitri, A. M. (2013) 'Analisis Faktor-Faktor Yang Berhubungan Dengan Kejadian Stres Kerja Pada Karyawan Bank (Studi Pada Karyawan Bank BMT)'. Jurnal Kesehatan Masyarakat 2013, 2 (1).

Gill, R. K. (2017) 'Burnout Related to Occupational Stress among Library and Information Professionals (LIS)', IOSR Journal of Humanities and Social Science, 22(4), pp. 60-65.

Heijnis, R. (2003) 'Organizational Stress: A Review and Critique of Theory, Research, and Applications', in Cooper, C., Dewe, P., and O'Driscoll, M. (eds) Gender, Work \& Organization. California: Sage Publications, pp. 130-131.
International Labour Organization (2016) Workplace Stress: a Collective Challenge. Geneva.

Irkhami, F. L (2015) 'Faktor Yang Berhubungan Dengan Stres Kerja Pada Penyelam Di PT. X', The Indonesian Journal of Occupational Safety and Health, 4 (1), pp: 54-63

Ministry of Manpower Republic of Indonesia (2018) Nomor 5 tahun 2018 tentang Keselamatan dan Kesehatan Kerja Lingkungan Kerja. Jakarta: Ministry of Manpower Republic of Indonesia.

Ng, T. W. H. and Feldman, D. C. (2012) 'Employee Voice Behavior: A Meta-Analytic Test of the Conservation of Resources Framework', Journal of Organizational Behaviour, 33(2), pp. 216-234.

Raza, S. et al. (2017) 'Workload, Work Stress, Role Conflict, and Workplace Deviant Behaviour in Banks : an Empirical Analysis Workload, Work Stress, Role Conflict, and Workplace Deviant Behaviour in Banks : an Empirical Analysis', European Online Journal Of Natural and Social Sciences, 6(4), pp. 701-707.

Rissen, D. (2006) Repetitive and Monotonous Work among Women. Sweden: Intellecta Docusys.

Routray, B. and Satpathy, S. K. (2007) 'Stress Management of Library \& Information Science Professionals in Digital Environment', in Librarianship in 21 st Century. Bhubaneswar: SBP Publisher, pp. 101-105.

Samosir, Zurni Z. and Syahfitri, I. (2008) Faktor Penyebab Stres Kerja Pustakawan pada Perpustakaan Universitas Sumatera Utara. Jurnal Studi Perpustakaan dan Informasi, 4 (2), pp. 61-69

Shelton, K. (2001) The Effects of Employee Development Programs on Job Satisfaction and Employee Retention. A Research Paper. Menomonie: Master of Science Degree, University of Wisconsin-Stout.

Shujaat, S. etal. (2013) 'Impact of Career Development on Employee Satisfaction in Private Banking Sector Karachi', Journal of Management and Social Sciences, 9(2), pp. 1-8.

Shupe, E. I., Brambleb, R. J. and Wambaugh, S. K. (2015) 'Role-Related Stress Experienced by Academic Librarian', The Journal of Academic Librarianship, 41(3), pp. 264-269.

Shupe, E. I. and Pung, S. K. (2011) 'Understanding the Changing Role of Academic Librarians: A Psychological Perspective', The Journal of Academic Librarianship, 37(5), pp. 409-415. 
Suci, Indah S. M. (2018) 'Correlation Of Individual Factors And Mental Workload With Job Stress', The Indonesian Journal of Occupational Safety and Health, 7 (2), pp. 220-229.

Tarwaka (2015) Ergonomi Industri: Dasar-Dasar Pengetahuan Ergonomi dan Aplikasi di Tempat Kerja. Surakarta: Harapan Press.

The National Institute for Occupational Safety and Health (NIOSH) (1998) Stress at Work. United State of America: Center for Disease Contro and Prevention.

The National Institute for Occupational Safety and Health (NIOSH) (2008) What are the causes of
Job Stress?. United State of America: Center for Disease Contro and Prevention.

Topper, E. F. (2007) 'Stress in the Library Workplace', New Library World, 108(11-12), pp. 561-564.

Umer, M. and Naseem, M. A. (2011) 'Employees Retention (Human Capital) in Business Process Outsourcing (BPO) Industry in Pakistan', Global Journal of Management and Business Research, 11(3), pp. 91-97.

Xiang, H. et al. (2014) 'Workplace Stress and Job Satisfaction among Biologics Development Professionals', Health, 06(14), pp. 1790-1802. 